\title{
Methodological Issues in Applied Social Psychology
}




\section{SOCIAL PSYCHOLOGICAL APPLICATIONS TO SOCIAL ISSUES}

Published under the auspices of the

Society for the Psychological Study of Social Issues

Volume 1 SOCIAL INFLUENCE PROCESSES AND PREVENTION

Edited by John Edwards, R. Scott Tindale,

Linda Heath, and Emil J. Posavac

Volume 2 METHODOLOGICAL ISSUES IN APPLIED SOCIAL PSYCHOLOGY

Edited by Fred B. Bryant, John Edwards,

R. Scott Tindale, Emil J. Posavac, Linda Heath,

Eaaron Henderson, and Yolanda Suarez-Balcazar

A Continuation Order Plan is available for this series. A continuation order will bring delivery of each new volume immediately upon publication. Volumes are billed only upon actual shipment. For further information please contact the publisher. 


\section{Methodological Issues in Applied Social Psychology}

Edited by

Fred B. Bryant, John Edwards, R. Scott Tindale, Emil J. Posavac, Linda Heath, Eaaron Henderson, and Yolanda Suarez-Balcazar

Loyola University of Chicago

Chicago, Illinois

A project of the faculty and students in the Applied Social Psychology Graduate Program at Loyola University of Chicago published under the auspices of the Society for the Psychological Study of Social Issues

Springer Science+Business Media, LLC 


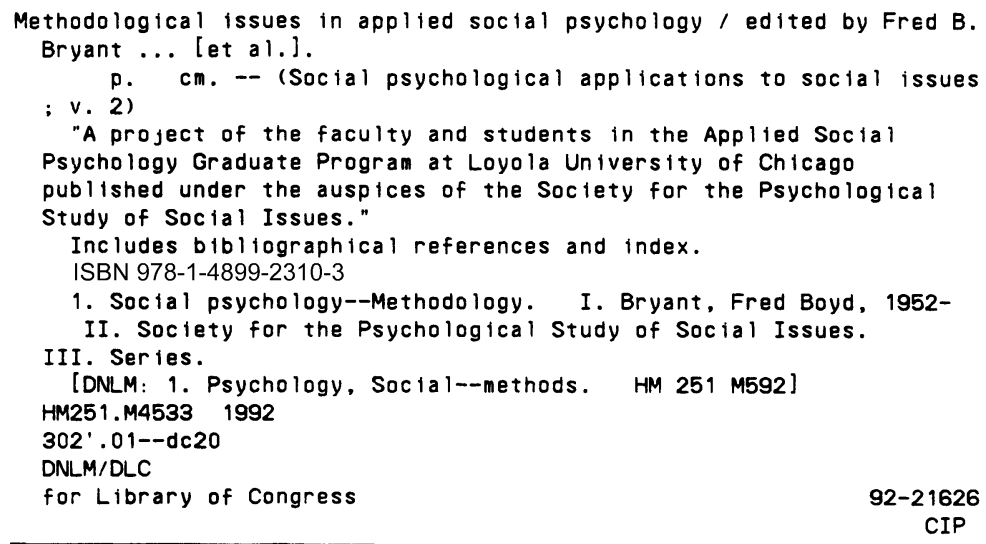

ISBN 978-1-4899-2310-3 ISBN 978-1-4899-2308-0 (eBook)

DOI 10.1007/978-1-4899-2308-0

(C) Springer Science+Business Media New York 1992

Originally published by Plenum Press, New York in 1992

Softcover reprint of the hardcover 1st edition 1992

All rights reserved

No part of this book may be reproduced, stored in a retrieval system, or transmitted in any form or by any means, electronic, mechanical, photocopying, microfilming, recording, or otherwise, without written permission from the Publisher. 


\title{
Editorial Advisory Board
}

\author{
Daniel Bar-Tal, Tel-Aviv University \\ Andrew S. Baum, Uniformed Services University of the Health Sciences \\ Sharon S. Brehm, University of Kansas \\ Marilynn B. Brewer, University of California, Los Angeles \\ Robert Cialdini, Arizona State University \\ James H. Davis, University of Illinois at Urbana-Champaign \\ Christine Dunkel-Schetter, University of California, Los Angeles \\ Ronald J. Fisher, University of Saskatchewan \\ Susan K. Green, University of Oregon \\ Christine Iijima Hall, Arizona State University \\ Sara B. Kiesler, Carnegie-Mellon University \\ Barbara J. Loken, University of Minnesota \\ Geoffrey Maruyama, University of Minnesota \\ Joseph E. McGrath, University of Illinois at Urbana-Champaign \\ Stuart Oskamp, Claremont Graduate School \\ Amado Padilla, Stanford University \\ Michael S. Pallak, American Biodyne \\ Daniel Perlman, University of British Columbia \\ Linda Perloff, Behavioral Measurement Database Services \\ Dennis P. Rosenbaum, University of Illinois at Chicago \\ Michael J. Saks, University of Iowa \\ Althea Smith, Boston University \\ Claude M. Steele, Stanford University \\ Geoffrey Stephenson, University of Kent at Canterbury \\ Tom Tyler, University of California, Berkeley \\ Carol M. Werner, University of Utah
}




\section{Contributors}

Fabricio E. Balcazar, University of Illinois at Chicago/UAP, Chicago, Illinois 60608

Peter M. Bentler, Department of Psychology, University of California, Los Angeles, California 90024

Leonard Bickman, Department of Psychology and Human Development, Vanderbilt University, Nashville, Tennessee 37203

Anita DeLongis, Department of Psychology, University of British Columbia, Vancouver, British Columbia V6T 1Z4 Canada

Stephen B. Fawcett, Department of Human Development, University of Kansas, Lawrence, Kansas 66045

Michelle Fine, CUNY Graduate School and University Center, New York, New York 10036

Kenneth J. Hemphill, Department of Psychology, University of British Columbia, Vancouver, British Columbia V6T 1Z4 Canada

Sara Kiesler, Department of Social and Decision Sciences, Carnegie Mellon University, Pittsburgh, Pennsylvania 15213

Darrin R. Lehman, Department of Psychology, University of British Columbia, Vancouver, British Columbia V6T 1Z4 Canada

Melvin M. Mark, Department of Psychology, Pennsylvania State University, University Park, Pennsylvania 16802

Jack McKillip, Department of Psychology, Southern Illinois University at Carbondale, Carbondale, Illinois 62901 
Richard E. Olmstead, Department of Psychology, University of California, Los Angeles, California 90024

Emil J. Posavac, Department of Psychology, Loyola University of Chicago, Chicago, Illinois 60626

Lawrence J. Sanna, Department of Psychology, Pennsylvania State University, University Park, Pennsylvania 16802

R. Lance Shotland, Department of Psychology, Pennsylvania State University, University Park, Pennsylvania 16802

Joan E. Sieber, Department of Psychology, California State University, Hayward, California 94542

James L. Sorensen, Langley Porter Psychiatric Institute, University of California, San Francisco, California 94110

Lee Sproull, School of Management, Boston University, Boston, Massachusetts 02215

Yolanda Suarez-Balcazar, Department of Psychology, Loyola University of Chicago, Chicago, Illinois 60626

R. Scott Tindale, Department of Psychology, Loyola University of Chicago, Chicago, Illinois 60626

Virginia Vanderslice, Praxis Associates, Philadelphia, Pennsylvania 19119

David A. Vollrath, Division of Business and Economics, Indiana University at South Bend, South Bend, Indiana 46634

John Walsh, Department of Sociology, University of Illinois at Chicago, Chicago, Illinois 60680

Paul M. Wortman, Department of Psychology, State University of New York at Stony Brook, Stony Brook, New York 11794

Paul R. Yarnold, Division of General Internal Medicine, Northwestern University Medical School, Chicago, Illinois 60611 


\section{Preface}

Many authors have argued that applying social psychology to the solution of realworld problems builds better theories. Observers have claimed, for example, that applied social psychology reveals more accurate principles of human behavior because its data are based on people in real-life circumstances (Helmreich, 1975; Saxe \& Fine, 1980), provides an opportunity to assess the ecological validity of generalizations derived from laboratory research (Ellsworth, 1977; Leventhal, 1980), and discloses important gaps in existing theories (Fisher, 1982; Mayo \& LaFrance, 1980). Undoubtedly, many concrete examples can be mustered in support of these claims.

But it also can be argued that applying social psychology to social issues and problems builds better research methods. Special methodological problems arise and new perspectives on old methodological problems emerge when researchers leave the laboratory and tackle social problems in real-world settings. Along the way, we not only improve existing research techniques but also develop new research tools, all of which enhance our ability to obtain valid results and thereby to understand and solve socially relevant problems. Indeed, Campbell and Stanley's (1966) seminal work on validity in research design grew out of the application of social science in field settings. In this spirit, the principal aim of this volume is to present examples of methodological advances being made as researchers apply social psychology in real-life settings.

Many methodological problems encountered in applied social psychological research have never before arisen in basic social psychological research. This is because of differences in objectives, settings, and research populations between the two fields. For example, applied research typically requires the establishment of clear, accepted operational definitions of dependent variables-a need that often dictates the assessment of multiple real-world behaviors, as opposed to laboratory analogues or simulations. This has led to the development of novel 
research techniques, such as structured diary methods, through which ongoing behaviors can be assessed over time in real-world settings (see Chapter 5, this volume, by DeLongis, Hemphill, \& Lehman).

In addition, applied social psychologists often have a greater need than do basic social psychologists to determine the latency and duration of treatment effects in actual application, so as to maximize the policy relevance of results and to facilitate cost-benefit analysis. This has led to the refinement of research procedures, such as time series analysis, which can be used to study groups in real-life settings over long periods (see Chapter 6 by Mark, Sanna, \& Shotland). Furthermore, in applied social research there is a greater need than in basic social research to explore variations in the ways treatments are implemented across sites and to discover unintended side effects that interventions may produce. This has led to the creation of techniques for using qualitative data reliably in empirical investigations (see Chapter 10 by Fine \& Vanderslice).

Perhaps the thorniest methodological problem encountered in applied social research is the need to draw unequivocal inferences about cause and effect in field settings. The frequent inability to rely on randomized experimental designs in applied research has led to a heightened awareness of specific threats to valid inference and has spawned a host of creative strategies for reducing the plausibility of these threats (e.g., Cook \& Campbell, 1979). It has also generated a variety of quasi-experimental research designs, such as the control construct design, that had been unavailable before (see Chapter 8 by McKillip).

This greater use of nonexperimental designs has also led to the refinement of existing analytic procedures, such as structural equations modeling, that are capable of detecting cause-and-effect relationships in longitudinal data (see Chapter 7 by Olmstead \& Bentler). In addition, researchers have creatively applied to quasi-experimental data such techniques as meta-analysis that were previously used only with randomized studies, and have improved these procedures in the process (see Chapter 4 by Wortman). Other applied researchers have developed innovative statistical techniques for analyzing data from nontraditional research methods, such as " $N$-of- 1 " designs, that had previously lacked statistical conclusion validity (see Chapter 9 by Yarnold).

Because applied social research often takes place in established organizational settings, it frequently requires a wider range of research skills than does traditional basic research. Applied researchers, for example, have had to learn how to plan and negotiate research arrangements in real-world settings, so as to obtain required resources (see Chapter 1 by Bickman); how to define research problems and solutions in ways that incorporate the views and priorities of multiple stakeholders (see Chapter 2 by Suarez-Balcazar, Balcazar, \& Fawcett and Chapter 10 by Fine \& Vanderslice); and how to communicate research results effectively to those who can use them (see Chapter 13 by Posavac). Applied 
social psychologists have also confronted a morass of ethical dilemmas unique to the study of human behavior outside the laboratory, and the insights gained have enabled them to devise research procedures that are both ethical and valid in the real world (see Chapter 3 by Sieber \& Sorensen).

Still other instances of methodological innovation in applied social psychology involve new methods that have sprung from advances in technology. A crucial catalyst in many of these cases has been the increased capability and availability of computers, which have made possible such new research techniques as computer-simulated "thought experiments" (see Chapter 11 by Tindale \& Vollrath) and electronic field studies (see Chapter 12 by Kiesler, Walsh, \& Sproull). One can only wonder what marvelous methodological inventions will evolve as this technology continues to develop.

The specific methodologies addressed in this volume range from commonly used procedures such as meta-analysis, time series designs, and structural equations modeling to less traditional approaches such as structured diary methods, control construct designs, and $N$-of- 1 analyses. We have chosen these particular methodologies not because of their prevalence in the field, but rather because they represent the tremendous diversity of approaches to data collection that characterizes applied social psychology. Numerous other methods (e.g., experience-sampling procedures, panel designs, focus groups, large-scale surveys, and a wealth of quasi-experimental designs) could have been included but for space limitations.

Research methods are tools for building knowledge, and knowledge is a tool for solving problems. Thus, research methods are ultimately problem-solving tools. As with other types of human implements, current methods have evolved from earlier methods and have been shaped by the forces of contemporary need, creative ingenuity, and technological expertise (see Clark, 1974; Larsen, 1961). This evolution entails endless trial and error, through which modern research tools are gradually refined by repeated field testing, much like the process of natural selection (see Basalla, 1988; Gilfillan, 1970).

Methodological advances in applied social psychology are driven by the need to solve meaningful practical problems. Tools that function well on the drawing board or in the controlled confines of the laboratory often fail to operate under rigorous real-world conditions, and when existing tools are inadequate, the ingenious artisan either modifies them to suit current needs or fashions new tools to accomplish the task.

This book presents examples of methodological advances being made as researchers turn from basic to more applied work. The authors of these chapters focus on what they have learned about a particular research method by using it to study problems in real-world settings. Drawing on actual cases of research application, they discuss the specific problems they encountered, the potential solu- 
tions they considered, and the methodological lessons they learned through hardwon experience.

These methodological applications encompass a wide variety of different content areas. Within the domain of health and medicine, for example, methodological lessons are presented from research on drug treatment and health care programs (see Chapter 3 by Sieber \& Sorensen), on the assessment of medical technology (see Chapter 4 by Wortman), on stress and coping (see Chapter 5 by DeLongis et al.), and on media campaigns for health promotion (see Chapter 8 by McKillip). Within the field of community psychology, methodological insights are presented from research on environmental obstacles to people with physical disabilities (see Chapter 2 by Suarez-Balcazar et al.), on the lives of "street people" (see Chapter 3 by Sieber \& Sorensen), and on the impact of community action groups (see Chapter 6 by Mark et al.). Within the realm of education, methodological lessons are presented from research on school desegregation and minority achievement (see Chapter 4 by Wortman) and on the restructuring of schools and school systems (see Chapter 10 by Fine \& Vanderslice). Within the area of criminal justice, methodological insights are presented from research on homicides and mass media violence (see Chapter 6 by Mark et al.) and on jury decision making (see Chapter 11 by Tindale \& Vollrath). Within the domain of interpersonal relations, methodological lessons are presented from research on friendship development (see Chapter 7 by Olmstead \& Bentler) and on the sharing of discretionary information in business organizations (see Chapter 12 by Kiesler et al.).

Although these applications have often yielded different methodological lessons, this variation is more a consequence of using different research methods than of studying different social problems. Methodological problems and solutions, like basic psychological processes, cross the boundaries of different content areas. Through cross-fertilization, lessons learned by researchers in one social-problem area may be used by researchers to avoid methodological problems in other areas.

Considered together, the chapters in this volume also cover many, if not all, aspects of the research process. The topics range from resource planning and problem identification to research design, data collection, analysis, and, finally, communication of results. In this sense, the volume represents a microcosm of the research process in applied social psychology.

The faculty and students of Loyola University's Applied Social Psychology Program are pleased to have the opportunity to work with the Society for the Psychological Study of Social Issues (SPSSI) and with Plenum Publishing Corporation in preparing this second volume in a series on social psychological processes and social issues. We hope that this book on methodological issues in applied social psychology will be useful to students and researchers in social psychology, by showing how the application of social psychology to social problems improves research methodology. 


\section{References}

Basalla, G. (1988). The evolution of technology. New York: Cambridge University Press.

Campbell, D. T., \& Stanley, J. C. (1966). Experimental and quasi-experimental designs for research. Chicago: Rand McNally.

Clark, R. W. (1974). The scientific breakthrough: The impact of modern invention. London: Nelson.

Cook, T. D., \& Campbell, D. T. (1979). Quasi-experimentation: Design and analysis issues for field settings. Chicago: Rand McNally.

Ellsworth, P. C. (1977). From abstract ideas to concrete instances: Some guidelines for choosing natural research settings. American Psychologist, 32, 604-615.

Fisher, R. J. (1982). Social psychology: An applied approach. New York: St. Martin's Press.

Gilfillan, S. C. (1970). The sociology of invention. Cambridge, MA: MIT Press.

Helmreich, R. L. (1975). Applied social psychology: The unfulfilled promise. Personality and Social Psychology Bulletin, 1, 548-560.

Larsen, E. (1961). A history of invention. New York: Roy.

Leventhal, H. (1980). Applied social psychological research: The salvation of substantive social psychological theory. In R. F. Kidd \& M. J. Saks (Eds.), Advances in applied social psychology (Vol. 1, pp. 190-193). Hillsdale, NJ: Erlbaum.

Mayo, C., \& LaFrance, M. (1980). Toward an applicable social psychology. In R. F. Kidd \& M. J. Saks (Eds.), Advances in applied social psychology (Vol. 1, pp. 81-96). Hillsdale, NJ: Erlbaum.

Saxe, L., \& Fine, M. (1980). Reorienting social psychology toward application: A methodological analysis. In L. Bickman (Ed.), Applied social psychology annual (Vol. 1, pp. 71-91). Beverly Hills, CA: Sage. 


\section{Acknowledgments}

This volume on methodological advances that stem from the application of social psychology is the product of the combined efforts of several organizations and of many individuals. It is the second in a planned series on applications of social psychological processes to social issues, and it involves the collaboration of SPSSI, Plenum Press, and Loyola University of Chicago's graduate program in applied social psychology.

We wish to thank the officers and publication committee of SPSSI for giving us the opportunity to edit this series and for their work and support in bringing to fruition the present collection of chapters. We would also like to thank the editorial and production staffs of Plenum Press, especially Eliot Werner, for their help in this project.

We extend our gratitude for their contributions in creating this book to the students in our graduate program who actively participated in researching possible topics and in writing reviews of initial drafts: Denise Archambault, Jill Carmody, Debbie Dilworth, Suzanne Farrell, Joseph Filkins, Marie MacKay, David Njus, Maureen O'Brien, Liz Sanders, Susan Sheffey, Christine Smith, Ed Torpy, Jerry Vasilias, and Kyle Weeks.

We gratefully acknowledge the 26 members of our Editorial Advisory Board for their advice and support in this particular project and for their constructive reviews of chapter drafts. We are especially grateful to Sharon Brehm, Marilynn Brewer, James H. Davis, Christine Dunkel-Schetter, Ronald Fisher, Sara Kiesler, Barbara Loken, Geoffrey Maruyama, Joseph McGrath, Stuart Oskamp, Amado Padilla, Michael Pallak, Daniel Perlman, Linda Perloff, Dennis Rosenbaum, Michael Saks, and Tom Tyler. We are also indebted to our colleagues Leonard Bickman, Al DeWolfe, Joe Durlak, Maryse Richards, and Judith Wittner for their helpful feedback on this project and on initial drafts of several of these chapters.

Finally, and most important, we thank the 25 authors for their efforts. Their 
hard work and creativity provide fresh insights into the research methods of applied social psychology and better enable us to use these valuable tools effectively.

Fred B. BRyant

JOHN EDWARDS

R. SCOTt Tindale

Emil J. Posavac

LINDA HEATH

EAARON HENDERSON

Yolanda SuAREZ-Balcazar 


\section{Contents}

1. Resource Planning for Applied Research $\ldots \ldots \ldots \ldots \ldots \ldots \ldots \ldots, 1$

Leonard Bickman

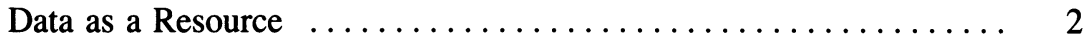

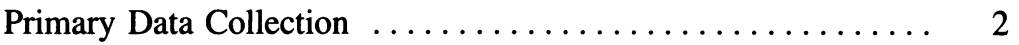

Secondary Data Analysis $\ldots \ldots \ldots \ldots \ldots \ldots \ldots \ldots \ldots \ldots$

Time as a Resource ......................... 9

Time and the Research Question $\ldots \ldots \ldots \ldots \ldots \ldots \ldots$

Time and Data Collection $\ldots \ldots \ldots \ldots \ldots \ldots \ldots \ldots \ldots \ldots$

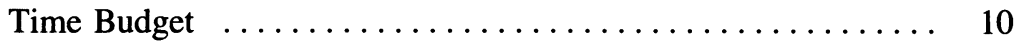

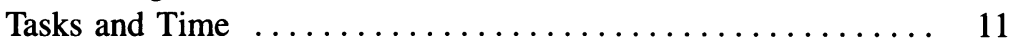

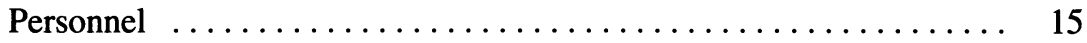

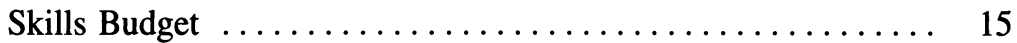

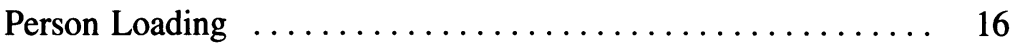

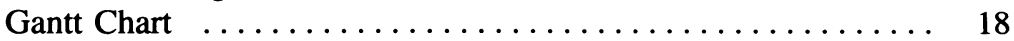

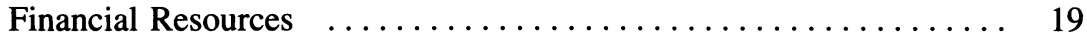

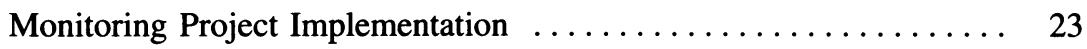

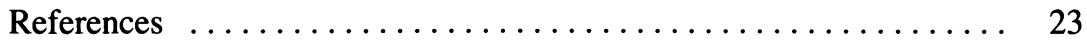

2. Problem Identification in Social Intervention Research $\ldots \ldots \ldots 25$

Yolanda Suarez-Balcazar, Fabricio E. Balcazar, and Stephen B. Fawcett

Conceptual Framework $\ldots \ldots \ldots \ldots \ldots \ldots \ldots \ldots \ldots \ldots \ldots \ldots$

Problem Identification and Analysis $\ldots \ldots \ldots \ldots \ldots \ldots \ldots \ldots . \ldots . \ldots 29$

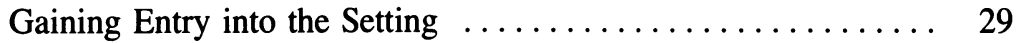

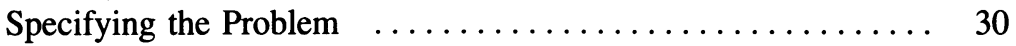

Analyzing the Problem $\ldots \ldots \ldots \ldots \ldots \ldots \ldots \ldots \ldots \ldots \ldots$ 


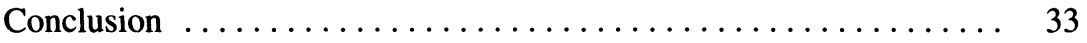

Case Study: Inappropriate Use of Handicapped-Parking Spaces $\ldots . .33$

Problem Identification and Analysis $\ldots \ldots \ldots \ldots \ldots \ldots \ldots . . \ldots \ldots$

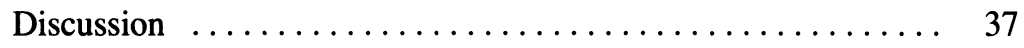

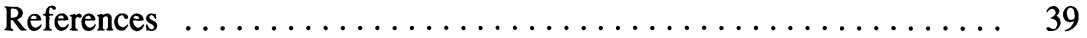

3. Ethical Issues in Community-Based Research and Intervention $\ldots .43$

Joan E. Sieber and James L. Sorensen

What Do We Mean by Ethics? ...................... 44

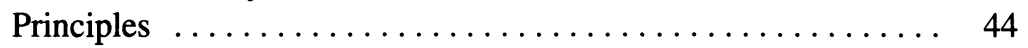

Norms of Ethical Research ................... 45

Selecting a Setting for the Research or Intervention $\ldots \ldots \ldots \ldots .47$

Street-Based Research $\ldots \ldots \ldots \ldots \ldots \ldots \ldots \ldots . \ldots 47$

Clinic-Based Research $\ldots \ldots \ldots \ldots \ldots \ldots \ldots \ldots \ldots .60 \ldots$

Designing Research to Fit the Setting $\ldots \ldots \ldots \ldots \ldots \ldots \ldots \ldots, 51$

A Process for Integrating Research into Drug Treatment $\ldots \ldots .53$

Designing Street-Based Research $\ldots \ldots \ldots \ldots \ldots \ldots \ldots \ldots . \ldots \ldots$

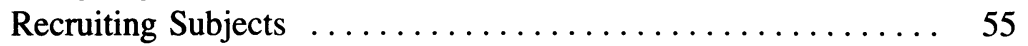

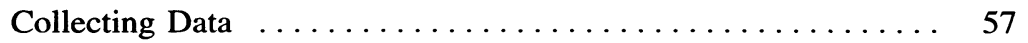

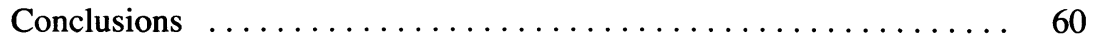

References $\ldots \ldots \ldots \ldots \ldots \ldots \ldots \ldots \ldots \ldots \ldots \ldots \ldots \ldots \ldots, 61$

4. Lessons from the Meta-Analysis of Quasi-Experiments $\ldots \ldots \ldots, 65$

Paul M. Wortman

The Case for Inclusion/Exclusion Criteria $\ldots \ldots \ldots \ldots \ldots \ldots .67$

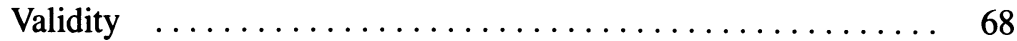

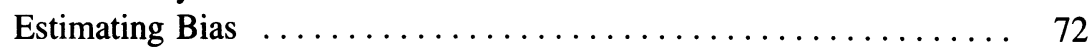

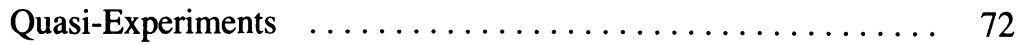

Randomized Experiments $\ldots \ldots \ldots \ldots \ldots \ldots \ldots \ldots \ldots \ldots$

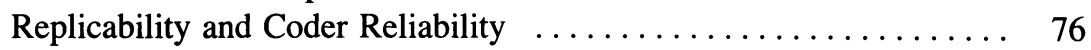

Generalizability .......................... 76

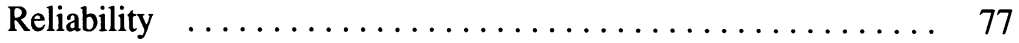

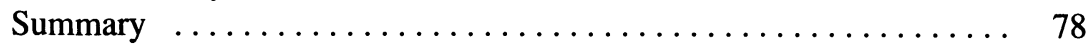

References $\ldots \ldots \ldots \ldots \ldots \ldots \ldots \ldots \ldots \ldots \ldots \ldots \ldots, 80$ 
Anita DeLongis, Kenneth J. Hemphill, and Darrin R. Lehman

Why Use a Structured Diary Methodology? .............. 85

The Confines of the Laboratory $\ldots \ldots \ldots \ldots \ldots \ldots \ldots$

The Study of Process $\ldots \ldots \ldots \ldots \ldots \ldots \ldots \ldots \ldots$

The Growing Interest in the Effects of Daily Events on Health and Mood $\ldots \ldots \ldots \ldots \ldots \ldots \ldots \ldots \ldots \ldots$

Increasing Predictive Ability via Aggregation across Time .... 90

Recall Error ........................... 90

Using the Diary Methodology: Potential Pitfalls and Possible

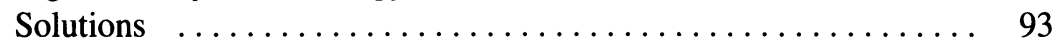

The Effects on Respondents of Participating in a Diary

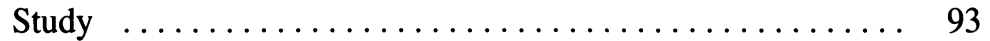

Sensitization Effects $\ldots \ldots \ldots \ldots \ldots \ldots \ldots \ldots \ldots \ldots \ldots . \ldots \ldots$

Refusal Rate Problems ....................... 95

Attrition and Missing Data Problems .............. 97

The Spacing and Number of Assessments across Time ...... . 98

Variations in Mood across the Days of the Week ... . . . . . . 99

Research Costs ........................ 100

Interpersonal Concerns with Diary Completions $\ldots \ldots \ldots \ldots . \ldots 100$

Accuracy of Diary Entries .................... 101

General Recommendations .................... 102

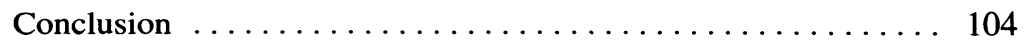

References ......................... 105

6. Time Series Methods in Applied Social Research $\ldots . \ldots \ldots \ldots . .111$

Melvin M. Mark, Lawrence J. Sanna, and R. Lance Shotland

Case Study 1: The Impact of a Community Action Group . . . . . . 112

Case Study 2: Mass Media Violence and Homicides (or, This Study

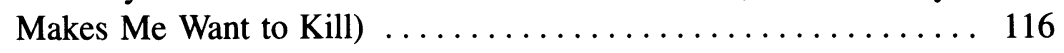

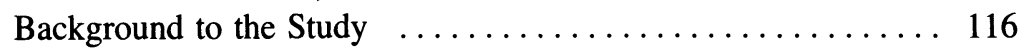

The Phillips (1983) Study $\ldots \ldots \ldots \ldots \ldots \ldots \ldots \ldots \ldots \ldots \ldots$

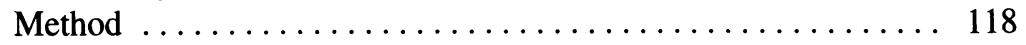

Analyses and Results $\ldots \ldots \ldots \ldots \ldots \ldots \ldots \ldots \ldots \ldots \ldots$ 
Beyond Case Studies: A Cursory Review of Time Series Studies

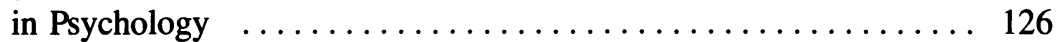

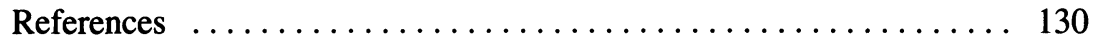

7. Structural Equations Modeling: A New Friend? ........... 135

Richard E. Olmstead and Peter M. Bentler

SEM: An Overview $\ldots \ldots \ldots \ldots \ldots \ldots \ldots \ldots \ldots \ldots \ldots \ldots$

Casual Hypotheses and Path Diagrams ........... 136

Equations and Model-Implied Correlations ............. 139

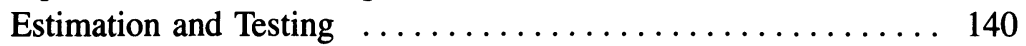

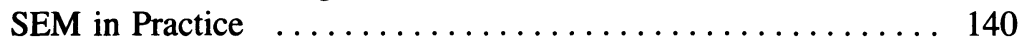

A Brief Review of the Theoretical Basis of the Friendship Model . . . . 141

Causes and Correlates of Attraction and Friendship ........... 142

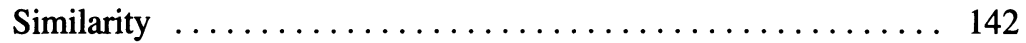

Physical Attractiveness $\ldots \ldots \ldots \ldots \ldots \ldots \ldots \ldots \ldots \ldots \ldots$

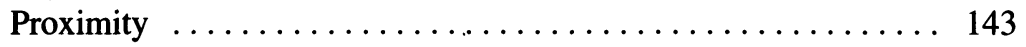

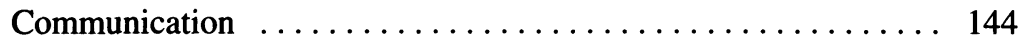

Common Fate ............................ 144

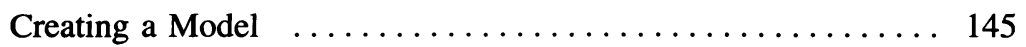

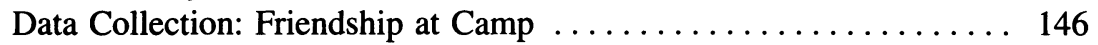

Data Source ........................ 146

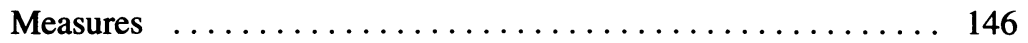

The Modeling Process $\ldots \ldots \ldots \ldots \ldots \ldots \ldots \ldots \ldots \ldots \ldots$

Testing the Initial Model $\ldots \ldots \ldots \ldots \ldots \ldots \ldots \ldots \ldots \ldots \ldots$

The Final Model $\ldots \ldots \ldots \ldots \ldots \ldots \ldots \ldots \ldots \ldots \ldots \ldots$

Discussion ........................... 154

Interpreting the Friendship Model $\ldots \ldots \ldots \ldots \ldots \ldots \ldots \ldots$

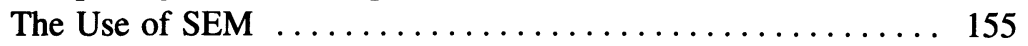

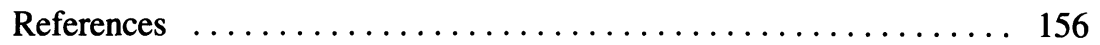

8. Research without Control Groups: A Control Construct Design ... 159 Jack McKillip

Problems with Control Groups $\ldots \ldots \ldots \ldots \ldots \ldots \ldots \ldots \ldots . \ldots \ldots$

Control Construct Design $\ldots \ldots \ldots \ldots \ldots \ldots \ldots \ldots \ldots \ldots \ldots \ldots \ldots \ldots$ 


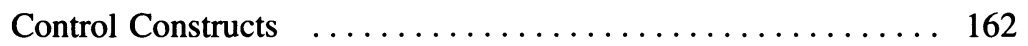

Multiple Observations ........................ 162

Abrupt Intervention .......................... 163

Contrast Weighting ........................... 164

Illustrating the Control Construct Design: A Health Media

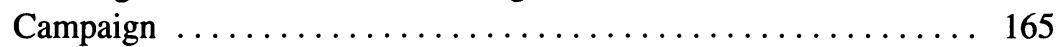

Research Methodology ...................... 166

Research Findings .......................... 168

Discussion .............................. 172

Limitations and Extensions of the Control Construct Design $\ldots \ldots .172$

References ............................... 174

9. Statistical Analysis for Single-Case Designs $\ldots \ldots \ldots \ldots \ldots \ldots 177$

Paul R. Yarnold

The Need for Statistical Analysis in $N$-of-1 Research $\ldots \ldots \ldots \ldots .178$

Hypotheses in $N$-of-1 Research $\ldots \ldots \ldots \ldots \ldots \ldots \ldots \ldots \ldots$

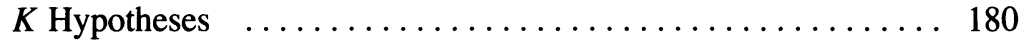

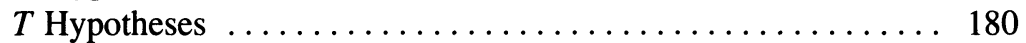

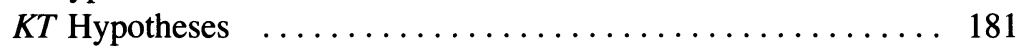

Statistical Analysis for $K$ Hypotheses $\ldots \ldots \ldots \ldots \ldots \ldots \ldots \ldots . \ldots \ldots$

Statistical Analysis for $T$ Hypotheses $\ldots \ldots \ldots \ldots \ldots \ldots \ldots . \ldots 184$

Statistical Analysis for $K T$ Hypotheses $\ldots \ldots \ldots \ldots \ldots \ldots \ldots \ldots . \ldots \ldots$

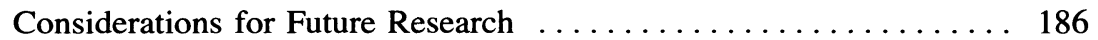

Minimizing the Magnitude of the Critical Difference Score ... 186

Standardizing Data ........................ 190

Selecting the Reliability Index $\ldots \ldots \ldots \ldots \ldots \ldots \ldots \ldots . \ldots 193$

$N$-of-1 Analysis as a Screening Tool ................. 194

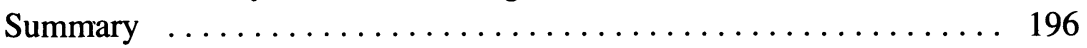

References ............................... 196

10. Qualitative Activist Research: Reflections on Methods and Politics

Michelle Fine and Virginia Vanderslice

Qualitative Activist Research ...................... 199

The Assumptions of Qualitative Activist Research ......... 201 
The Transforming Role of Researchers $\ldots \ldots \ldots \ldots \ldots \ldots \ldots .201$

Reconceptualizing the Collection of Data ............ 203

Generating Grounded Theory at Multiple Levels of Power and Practice ............................... 205

Assumptions in Summary .................... 206

The Philadelphia Schools Collaborative $\ldots \ldots \ldots \ldots \ldots \ldots \ldots 207$

Activist Research .......................... 208

Phoenix High: Rising from the Ashes $\ldots \ldots \ldots \ldots \ldots \ldots \ldots \ldots . \ldots 208$

Teachers as Researchers ....................... 209

Research to Legitimate Multiple Perspectives: At the School and at the District ....................... 212

The Dialectic of Theory and Practice in Activist Research:

On Surprises . ............................. 213

Reflections on Activist Research $\ldots \ldots \ldots \ldots \ldots \ldots \ldots \ldots \ldots . \ldots \ldots$

References .............................. 217

11. "Thought Experiments" and Applied Social Psychology $\ldots . . .219$

R. Scott Tindale and David A. Vollrath

Social Decision Scheme Theory $\ldots \ldots \ldots \ldots \ldots \ldots \ldots \ldots \ldots 220$

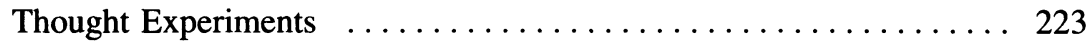

Grand Jury Size and Decision Rule ................ 223

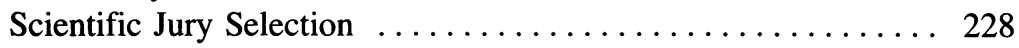

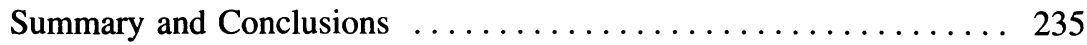

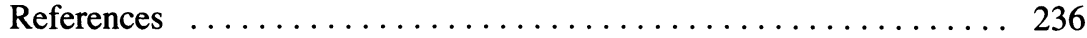

12. Computer Networks in Field Research $\ldots \ldots \ldots \ldots \ldots \ldots \ldots .239$

Sara Kiesler, John Walsh, and Lee Sproull

Development of Networks $\ldots \ldots \ldots \ldots \ldots \ldots \ldots \ldots \ldots \ldots . \ldots . \ldots . \ldots 240$

Data Collection on Networks ..................... 242

Advantages of Network Data Collection .............. 243

Disadvantages of Network Data Collection $\ldots \ldots \ldots \ldots \ldots 248$

New Data and Different Questions $\ldots \ldots \ldots \ldots \ldots \ldots \ldots \ldots 251$

Reaching Remote People through Surveys $\ldots \ldots \ldots \ldots \ldots . \ldots 251$

Event-Driven Computer Surveys $\ldots \ldots \ldots \ldots \ldots \ldots \ldots . \ldots 252$ 
Ethnographic Studies of On-Line Behavior ............ 253

Studies Using Computer Data Bases and Archives ........ 258

Action Research ........................... 261

Networks as an Intervention in the Social World .......... 262

Conclusion ................................... 264

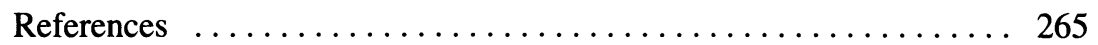

13. Communicating Applied Social Psychology to Users:

A Challenge and an Art $\ldots . \ldots \ldots \ldots \ldots \ldots \ldots \ldots \ldots \ldots .269$

Emil J. Posavac

Communication and Applied Social Psychologists ........... 270

Who Is an Applied Social Psychologist? .............. 270

Attitude Change Processes and the Communication of Applied

Social Psychology ........................... 271

Problems in Communicating with People Who Might Apply

Social Psychology ............................. 273

Credibility is Broader than Being Smart and Well Read ...... 273

Journal Article Style Offers Little Help in Designing Policy or in Developing Interventions ................... 273

Standard Descriptions of Statistical Findings

Are Misunderstood ............................ 275

Expect Audiences to Be Defensive ................ 276

Two Frequently Observed Cognitive Biases Leading

to Misinterpretations ...................... 278

Improving the Chances of Being Listened to and Understood .... 279

Begin with a Communication Plan $\ldots \ldots \ldots \ldots \ldots \ldots \ldots 280$

Work in a Way to Increase Credibility $\ldots \ldots \ldots \ldots \ldots \ldots . \ldots 282$

Present an Understandable Message ............... 283

Make Communications Specific and Concrete ........... 284

Use Multiple Channels ........................ 286

Hint on Reporting Statistics: Keep It Simple . . . . . . . . 287

Involve the Audience in the Presentation ............. 290

Keep Recommendations within the Psychological Reach of the Client $\ldots \ldots \ldots \ldots \ldots \ldots \ldots \ldots \ldots \ldots \ldots . \ldots . \ldots 291$

Remember the Limitations of and the Pressures on the Audience ............................ 292

References .............................. 292 